\title{
Cultural and Institutional Differences at the National and Regional Levels
}

\author{
Bagrat Yerznkyan ${ }^{1}$, Lily Gassner ${ }^{2}$ \\ ${ }^{1}$ Central Economics and Mathematics Institute, Russian Academy of Sciences, Moscow, Russian Federation \\ ${ }^{2}$ Human Resources, Hewlett-Packard Enterprise, Roseville, USA \\ Email address: \\ lvova1955@mail.ru(B. Yerznkyan),yerz@cemi.rssi.ru(B. Yerznkyan), lily.gassner@hpe.com(L. Gassner)
}

To cite this article:

Bagrat Yerznkyan, Lily Gassner. Cultural and Institutional Differences at the National and Regional Levels. International Journal of Economics, Finance and Management Sciences. Vol. 6, No. 4, 2018, pp. 133-138. doi: 10.11648/j.ijefm.20180604.11

Received: May 10, 2018; Accepted: June 7, 2018; Published: June 29, 2018

\begin{abstract}
Culture and institutions are two related phenomena contributing to economic performance. Culture is transmitted via teaching and imitation, while institutions, especially informal ones, come from socially transformed information and as such they are close to culture. The purpose of this paper is to examine the cultural and institutional issues of economic development with emphasis on their differences which may play a key role in understanding the very nature of socio-economic development. In a paper, the influence of culture and institutions on the socio-economic development in relation to the stationary (developed) economy as well as to the non-stationary (developing, transitional) economy is discussed. In addition, varieties of economic systems are considered. Main conclusions: (1) National specificity is superimposed on genetics: on the whole, Western civilizations with their inherent two-valued logic of thinking and the dominance of open access orders in society are more prone to economic exchanges - transactions, while Eastern civilizations, with their multi-valued logic and limited access orders, on the contrary, are more prone to social exchange processes - interactions. (2) The restructuring of the world in American terms is ontologically meaningless and conceptually erroneous, because of universality of the requirement of an inordinate consideration of national characteristics - taking into account that even in the USA the coexistence of heterogeneous political subcultures is a reality that cannot be ignored. (3) The relevance of culture and institutions are of particular importance in reforming the economy. As shows the Russian reforms, political factors, with uncritical import of formal institutions, rather than economic ones played a significantly greater role in changing its trajectory of development.
\end{abstract}

Keywords: Culture, Institution, Region, Nation, Market-Oriented Reform

\section{Introduction: Culture and Institutions}

Culture and institutions are two related phenomena contributing to economic performance (Yerznkyan et al., 2017 [1]). They matter because of the ability to influence economic activity as well as because of presence of variety of economic systems. Bruno Amable, for example, distinguishes five [ideal] types of contemporary capitalism (market-based, social democratic, Asian, continental European, South European), explaining this multiplicity by institutional complementarity (close to that developed in (Aoki, 2001 [2]), as well as institutional hierarchy (Amable, 2003 [3]). Other scholars find even more types of historical and modern models of capitalism.

Culture and institutions may be well enough understood in the language of information transmission "from one generation to the next, via teaching and imitation, of knowledge, values, and other factors that influence behavior" (Boyd, Richerson, 1985, p. 2 [4]). In a turn, institutions understood as informal constraints "come from socially transmitted information and are part of the heritage that we call culture" (North, 1990, p. 37 [5]).

As for institutions, Douglass North gives at least two definitions:

1. Institutions are sets of rules, compliance procedures, and moral and ethical behavioral norms designed to constrain the behavior of individuals in the interests of maximizing the wealth or utility of principals (North, 1981, 
p. $202[6])$.

2. Institutions are the rules of the game in society or, more formally, are the humanly devised constraints that shape human interaction. In consequence they structure incentives in human exchange, whether political, social, or economic (North, 1990, p. 3 [5]).

Such treatment of institutions is closer to the 'new' rather than the 'old' institutional economics. North regards institutions as constraining agents and channeling their incentives, i.e. institutions act primary as constraints upon the behavior of given individuals and channel unchanging incentives; hence purposes or preferences are themselves changed by institutions. In fact, North treats institutions as environment systems.

To understand this statement, one can address to George Kleiner definition of system as a relatively independent part of the environment, stable in time and space, possessing both the properties of external integrity and internal diversity. A basic typology of economic systems includes a notion of system as: object (a part of the external world, which exists outside a person), environment (a more or less homogenous matter filling space), process (a cyclical pattern of a phenomenon's development) and project (a sequence of steps aimed at achieving a specific goal within a specified time period). Thus, they are not only the most significant and widely researched part of economic phenomena and systems but, in fact, exhaust the variety of their types (Kleiner, 2009, pp. 9-10 [7]).

In accordance with this representation of a system as $\mathrm{S}=\left\{\mathrm{S}_{1}, \mathrm{~S}_{2}, \mathrm{~S}_{3}, \mathrm{~S}_{4}\right\}$, where $\mathrm{S}_{1}$ is object, $\mathrm{S}_{2}$ - environment, $\mathrm{S}_{3}$ - process, $\mathrm{S}_{4}-$ project, it is to give the system interpretation of the semantically plural institution $\mathrm{I}=\left\{\mathrm{I}_{1}, \mathrm{I}_{2}, \mathrm{I}_{3}, \mathrm{I}_{4}\right\}$, where $\mathrm{I}_{1}, \mathrm{I}_{2}, \mathrm{I}_{3}$, and $\mathrm{I}_{4}$ represent this institution in form of object, environment, process and project, respectively. Such an approach allows the operating with different institutions, first classifying them, identifying them depending on the research objectives as one or another type. It is especially emphasized the dependence of the choice of the type of the institute on the objectives of the research: in some cases it is appropriate focus on the same type of institution. See the features of these institutional and, at the same time, system types in (Yerznkyan, 2016a [8]).

The spatial differences in the effect of agents immersed in this or that - stationary or non-stationary - institutional and cultural environment are shown in (Yerznkyan, Gassner, 2017 [9]), on which, among other things, the success of the reforming the economic system, in particular, its transformation from a non-stationary state to a stationary economy.

The paper is organized as follows: section 2 reviews national specificity of culture and institutions. Section 3 reviews the regional differences of culture on the examples of Italian regional governments and the main North-American subcultures types and styles of culture regarded as system. Section 4 is devoted to the importance of culture and institutions in reforming the economy. And, finally, section 5 is a conclusion.

\section{National Specificity of Culture and Institutions}

For an adequate description of national specificity and features of human nature, and, therefore, the behavior of economic agents, it is necessary to take into account, as for Francis Fukuyama, genetic (in the form of propensities or predispositions) and cultural factors (fixed by means of the learning mechanism) factors (Fukuyama, 1999 [10]).

National specificity is superimposed on genetics: on the whole, Western civilizations with their inherent two-valued logic of thinking and the dominance of open access orders in society are more prone to economic exchanges transactions, while Eastern civilizations, with their multivalued logic and limited access orders, on the contrary, are more prone to social exchange processes - interactions. It is about propensity (possibility or probability), and not about certainty: Western people in certain circumstances may prefer social markets to economic ones, and vice versa - people in the East can give preference to economic markets over the social ones. It should be emphasized that in this context the concepts of the West and the East are rather conditional: their features can be evident in Russia as well, which is characterized by a high degree of regional differentiation and, additionally, an individual-personal one.

Turning to the experience of developed countries, one can find striking differences between what they had and what they have to offer as a role model. Historical experience testifies to the second point of view (first development, then institutions), but attempts to prove - consciously or not - the rightness of the first (first institutions, then development). There is a definite reason for this: in developed countries, economic development (achieved with existing, though perhaps not permanent, institutions) occurred before major institutional changes, creating a stable basis and opening the way for the modernization of institutions relevant to the socioeconomic dynamics of these countries. In any case, as analysis of approaches to institutions and development shows, "one can not view institutions as an unconditional prerequisite for development - without reference to the specifics of the historical path of development, established institutions and many other factors of the social, cultural, organizational, political, economic nature of a particular country" (Yerznkyan et al., 2014, p. 29 [11]).

To illustrate the possibility of transferring national differences, in (Yerznkyan, 2013 a, b [12; 13]) a five-point distribution of countries is proposed according to the descending role and significance of the market in them: the limiting case of market transactions is 5 , USA - 4, Germany -3 , Russia -2 , Japan -1 , non-market interactions -0 . The propensity to market interaction, or predisposition to transactions, can be reflected as: $1 ; 0.8 ; 0.6 ; 0.4 ; 0.2$ and finally 0 respectively. The types of real countries with poles are not identifiable intentionally, since in reality there is no 
other repressive of one component, and they co-exist with one degree of domination or another. The fact is that in any country, with a certain generality of national inclination, regional, confessional, ethno-cultural and other differences may manifest themselves. Take, for example, the United States (see their sub-cultural differences in section 3).

Consider now national specificity of culture and institutions related to a concrete case of income distribution on the example of a country taking in some sense a middle position between USA and Russia, namely the Netherlands.

Observation of cultural foundation of income distribution leads Dutch scholars Piet Keizer and Antoon Spithoven to the conclusion that countries like the Netherlands, known as corporatist ones, "should stick to their culture, even now when their economies are globalizing". What follows from this for economic theory is that: "the cultural aspect of human behavior is essential when trying to understand important economic developments such as distribution and productivity" (Keizer, Spithoven, 2009, p. 521 [14]).

It should be especially underlined that in the foundation of corporatist culture lays the idea of participation of everyone and close cooperation between different societal groups. It follows from the very basic principles of corporatism: "1) everyone ought to participate; 2) everyone ought to give and take; and 3) those that are most experienced, and have shown themselves to be the responsible persons and organizations must have to lead" (ibid, p. 515 [14]).

This observation and corresponding interpretation relates to the participation of everybody. As for the interaction of groups, the same Dutch experience shows that "corporatism arose as a result of the process of emancipation of Protestants, Socialists and Roman Catholics that took place in the second half of the nineteenth century" (ibid, p. 516 [14]). The expression of this process was the creation by all groups of their own organizations in important spheres of society - this process was called the pillarization of society (Lijphart, 1968 [15]), hinting that these organizations served as a form of public pillars.

\section{Regional Sub-Cultures: Evidences from Italy and USA}

From the very beginning of observing the regional subcultures, the requirement of an inordinate consideration of national characteristics is universal: it applies not only to developing and transitional countries, but also to fully industrialized and institutionally developed countries, as well as to regions within these countries.

Thus, in one of the works on social capital in Italy (Putnam et al., 1993 [16]), the consequences of institutional changes in Italy in the 1970 s are depicted, where the central government established 15 regional governments. It would seem that they all had to function more or less in a single key and come to similar results. In practice, everything turned out differently. And the reason was the deep differences between the central-northern and southern regions which date back centuries.

Analysis of the main characteristics of social capital cooperation, participation, social interaction and trust - led the authors to the hypothesis that the origins of regional differences lie in the cultural and institutional plane. Regions in which the institutions of free cities (free cities) - with the beginnings of participative democracy, political organization, providing their citizens with public goods, etc. were developed in the Middle Ages - were more advanced in the sense of civil and cooperative behavior of their citizens, whose culture was transmitted from generation to generation (Alesina, Giuliano, 2013, p. 2 [17]).

And now let us turn to the experience of the United States, which often and, as a rule, uncritically, is presented as an example for borrowing. The reference to the non-critical character of such borrowing is justified by the fact that the institutions recommended as a model for imitation economic (free market), political (democracy and electivity), legal (power in the state are not elites, but rights) - "are not culturally neutral." Special attention is paid to this by L. P. and R. N. Evstigneevs in their analysis of the problems of the reducibility of mentality to rationalization and democratization: "it is not only a technological and cultural problem", but "a historical problem concerning the correlation (unity and difference) of socio-cultural epochs" (Evstigneeva, Evstigneev, 2011, p. 89 [18]).

To begin with, the restructuring of the world in American terms is ontologically meaningless and conceptually erroneous, if only because there is no uniform stereotype of the social structure shared by all states in the United States: at least three subcultures coexist in the US - political cultureindividualistic or individualistic (individualistic), moralistic (moralistic), and traditionalistic (traditional) (Elazar, 1966 [19]). The roots of these subcultures go into opposition to the "marketplace" (the pursuit by individuals of their own interests in the market and through the market) and the commonwealth (the cooperation of individuals for achieving common goals rooted in moral principles)", with more or less pronounced regional localization (Wirt, 1991, p. 4 [20]).

These subcultures can be ranked in different ways: from 1 to 7 , from 1 to 9 . If one evaluates citizenship-oriented policies as 1, and business stimulation policies as 7, subcultures on a linear scale are arranged as follows: moralistic (1) - individualistic (4) - traditionalist (7). Between these pure states there can be subcultures-hybrids, when considering the form of the full picture: I (1), M/I (2), $\mathrm{I} / \mathrm{M}$ (3), I (4), I/T (5), T/I (6), and, finally, $\mathrm{T}$ (7) (Boeckelman, 1991, pp. 53-55 [21]). So, if in the US the coexistence of heterogeneous political subcultures is a reality that cannot be ignored, as in this case it is possible without the knowledge of the historically developed (and continuing to evolve) reality of countries, even those who need reforms to recommend them the adoption of the same institutions, whose suitability is perhaps speculative?

Even in Washington, writes Joseph Stiglitz, there was a consensus that the Washington consensus is not good for America - whatever its dignity for the rest of the world, or 
how it would not serve American interests, forcing others to do what America does not do at home (Stiglitz, 2003 [22]). For comparison, let us remember the words of Academician Dmitry S. Lvov: "the ideology of the Washington Consensus was and remains an ideology for others, but not for governments and countries of the golden billion" (Lvov, 2005 , p. 42 [23]). It is remarkable the recognition of former Deputy Prime Minister and Minister of Finance of Poland Grzegorz Kolodko about the timing of the choice and the way in which institutional changes are implemented in Eastern European countries for political rather than economic reasons. Although this conclusion may disappoint economists, we stand by: "Political factors rather than economic factors played a significantly greater role in changing the course of history" (Kolodko, 2000, p. 329 [24]).

\section{Culture and Institutions in Reforming the Economy}

The relevance of culture is of particular importance in reforming the economy. In (Martishin, 2015 [25]), it is shown that the strategy of reforms depends on the nature of the economic systems, assuming the measure of the gradual and radical development processes is based on the internal systems of genotypic regularities, which include the conservative and liberal lifestyles, their change and unity. To effectively reform Russia, the Russian genotype mutations, characterized by the excessive dominance of conservatory order, need to be eliminated. This can be done through an evolutionary reform strategy, assuming both the transformation of the old order and the gradual construction of genotypic economic models. Institutional trajectory of modernization should start with the «top» level of the existing features of economic systems and be concluded with the consideration of the general genotypic regularities of the global economic system, which does not deny the cultural and socio-economic features of the countries and regions. See also (Arkhipov et al., 2015 [26]), where the authors analyze evolutionary-institutional patterns and factors of economic growth and development on the example of a number of countries, which have demonstrated the "economic miracle".

Cultural and institutional differences are reality: "each time and each country is different", claims Stiglitz and asks rhetoric questions: "Would other countries have met the same success if they had followed East Asia's strategy? Would the strategies which worked a quarter of a century ago work in today's global economy? Economists can disagree about the answers to these questions. But countries need to consider the alternatives and, through democratic political processes, make these choices for themselves. It should be - and it should have been - the task of the international economic institutions to provide the countries the wherewithal to make these informed choices on their own, with an understanding of the consequences and risks of each" (Stiglitz, 2002, p. 88 [27]).

There is another example, comparing two neighboring countries in Asia - China and India (Yerznkyan et al., 2017, p. 74 [1]). The differences between the two are not only in culture, but also in terms of doing business and making foreign investments. Table 1 is an illustration of these differences, including culture, as well as the economic and political aspects.

Table 1. Example of the Cultural and Other Differences between China and India.

\begin{tabular}{|c|c|c|}
\hline Country & China & India \\
\hline $\begin{array}{l}\text { Political and social } \\
\text { differences }\end{array}$ & $\begin{array}{l}\text { Autocracy. Unitary state } \\
\text { Leading role of one party } \\
\text { Strong role of state ideology Mostly homogenous society } \\
\text { Social class equality } \\
\text { Relative success in fast poverty reduction }\end{array}$ & $\begin{array}{l}\text { Federal democracy } \\
\text { Multiparty system } \\
\text { Pluralism } \\
\text { Variety of languages, religions and cultures } \\
\text { Caste system } \\
\text { Absolute poverty country Disparity increases }\end{array}$ \\
\hline Economic policy & $\begin{array}{l}\text { Reforms began in } 1979 \\
\text { Faster pace. Leader in FDI attractiveness } \\
\text { Follows classical development route: Agriculture => Manufacturing => } \\
\text { Services } \\
\text { Export oriented manufacturing model } \\
\text { Low cost manufacturing strategy } \\
\text { Strong use of Diaspora capital } \\
\text { Continuous flow of policies to build infrastructure, improve business } \\
\text { climate } \\
\text { Policies well planned and implemented } \\
\text { Flexible labor laws. Merit-based system introduced } \\
\text { Large size of Special Economic Zones } \\
\text { Efficient tax holidays, export promotion, tax exemption on imported } \\
\text { machinery, liberal entry and exit policies }\end{array}$ & $\begin{array}{l}\text { Reforms began in } 1991 \\
\text { Slower pace. Laggard in investor confidence } \\
\text { Different to classical development route: Agriculture => } \\
\text { Services (skipped the Manufacturing sector) } \\
\text { Import substituting manufacturing model } \\
\text { Skill intensive and services sector growth strategy } \\
\text { Poor use of Diaspora capital } \\
\text { Inconsistent policy in developing infrastructure } \\
\text { No clear policy guidelines } \\
\text { Rigid labor law } \\
\text { Small size of Special Economic Zones } \\
\text { Case by case basis in treatment of foreign investors. } \\
\text { More place for corruption }\end{array}$ \\
\hline Cultural aspects & $\begin{array}{l}\text { Poor knowledge of English } \\
\text { Relation-oriented managers }\end{array}$ & $\begin{array}{l}\text { Good English language skills } \\
\text { Project-oriented managers }\end{array}$ \\
\hline
\end{tabular}

Source: (Vardanyan, 2011, p. 108 [28]).

In spite of many differences, there are some similarities between these two neighboring countries, as it relates to their 
economic development. They are as follows: (i) in both countries the economic success is based on implementation of large-scale process of reforms, which are constantly under review by the government; (ii) both use a five-year plan as a framework of economic policy and designing of reforms; (iii) both employ economic instruments, e.g. attraction of Foreign Direct Investment (FDI) through fiscal incentive, to increase country competitiveness; (iv) both countries created free trade zones to accommodate foreign investments: Special Economic Zones in China and Export Processing Zones in India; (v) the governments of both countries are willing to tackle the regional development problem and related issues to provide sustainable economic growth (Yerznkyan et al.,
2017, p. 75 [1]).

Nowadays, China and India keep each other in their eyesight and view each other as competition. One of the current distinctions between China as the 'factory of the world' and India as the 'world's back office' in international trade may be changing in the coming decade, since China is aiming to develop its service sectors, whereas India hopes to move towards skill-neutral mass manufacturing (Vardanyan, 2011, pp. 107-109 [28]).

To understand the differences between reform characteristics and cultural specificity, let us juxtapose Russia and China (see Table 2).

Table 2. Cultural and Institutional Differences and Market-Oriented Reform in Russia and China.

\begin{tabular}{|c|c|c|}
\hline Reform and cultural-institutional indicators & $\begin{array}{ll}\text { Country } & \text { Russia }\end{array}$ & China \\
\hline Level of development before reform & High & Low \\
\hline Decline during reform & Significant & No decline \\
\hline Growth rate after reform & Low & High \\
\hline Sequence of reform & Politics first & Economy first \\
\hline Pace of reform & Rapid & Gradual \\
\hline Initiative of reform & Top-down & Middle-up \\
\hline Spirit of reform & Shock therapy & Controlled transition \\
\hline Nation's propensity to revolution & Rather strong & Rather weak \\
\hline Western advice (neo-liberal recipes) & Strong influence & No influence \\
\hline Language & Synthetic & Analytic \\
\hline
\end{tabular}

Source: derived from tables in (Yerznkyan, 2014, p. 67 [29]; Rutland, 2009, p. 53 [30]).

From 1978 up to now, China has enjoyed average economic growth of roughly $10 \%$ a year, just like Japan has over the earlier three decades, i.e. from the mid-1950s to the mid-1970s. As to Russia, the reforms much more recent - in the 1990s - can be used to compare with those of China to cover the spectrum of institutional change and cultural evolution, though "we still are a long way from having any neat models of cultural evolution" (North, 1990, p. 44 [5]). However, it is rather unquestionable that cultural traits have tenacious survival ability and that most cultural changes are incremental, not decremental, and as such they essentially matter.

\section{Conclusion}

Culture and institutions, especially the informal ones, such as codes of conduct, norms of behavior, and conventions, being two closely related phenomena, have the ability to impact economic performance.

The purpose of the study in this paper was an attempt to attract attention to the importance of culture and institutions to better understand economic processes at the regional and other levels. In fact, the importance of cultural component has not only the spatial but also the temporal dimension and it connects all levels of study human civilization development as whole.

The main conclusions of this paper are as follows: (i) national specificity is superimposed on genetics: on the whole, Western civilizations with their inherent two-valued logic of thinking and the dominance of open access orders in society are more prone to economic exchanges transactions, while Eastern civilizations, with their multivalued logic and limited access orders, on the contrary, are more prone to social exchange processes - interactions; (ii) the restructuring of the world in American terms is ontologically meaningless and conceptually erroneous, because of universality of the requirement of an inordinate consideration of national characteristics - taking into account that even in the USA the coexistence of heterogeneous political subcultures is a reality that cannot be ignored; (iii) the relevance of culture and institutions are of particular importance during reforms, when political factors and uncritical import of formal institutions rather than economic factors played a significantly greater role in changing the economy.

Culture and institutions matter because of their deeper and more holistic ability to construct the economic reality as such. There are a lot of dimensions for culturally predetermined reality, including morality and related issues. As for Pope John Paul, a culture that no longer has a point of relevance in God loses its soul and loses its way, becoming a culture of death. Detached from their Christian origins, these models are often inspired by an approach to life marked by secularism and practical atheism and by patterns of radical individualism. These words are in accordance with the insights of Dmitry Lvov presented by him as a strategy for Russia's breakthrough to the desirable stationary independent future in a sense that the strategy includes the attitude towards people and connected with it factors of culture - the system of public revenue distribution, the social conditions, 
the distortions occurred after voucher privatization scheme, system of state property, relation to rent and other items aimed at the spiritual and moral renaissance of the nation that is the starting point for the breakthrough.

\section{References}

[1] Yerznkyan, B., Gassner, L., Kara, A. (2017). Culture, Institutions, and Economic Performance. Montenegrin Journal of Economics, 13, 2: 71-80.

[2] Aoki, M. T (2001). Toward a Comparative Institutional Analysis. Cambridge, MA: MIT Press.

[3] Amable, B. (2003). The Diversity of Modern Capitalisms. Oxford: Oxford University Press.

[4] Boyd, R., Richerson, P. J. (1985). Culture and the Evolutionary Process. Chicago: University of Chicago Press.

[5] North, D. C. (1990). Institutions, Institutional Change and Economic Performance. Cambridge: Cambridge University Press.

[6] North, D. (1981). Structure and Change in Economic History. New York: Norton.

[7] Kleiner, G. B. (2009). A New Theory of Economic Systems and Its Application to Economic Policy Studies. Hitotsubashi [University] Invited Fellow Program. Discussion Paper Series, 14.

[8] Yerznkyan, B. H. (2016a). The Influence of Culture on the Economic Behavior. Theory and Practice of Institutional Reforms in Russia / Collection of scientific works ed. by B. H. Yerznkyan. Issue 35. Moscow: CEMI RAS, 78-87.

[9] Yerznkyan, B., Gassner, L. (2017). On the Measurement of Institutions and Culture. Theory and Practice of Institutional Reforms in Russia / Collection of scientific works ed. by B. H. Yerznkyan. Issue 39. Moscow, CEMI RAS, 73-82.

[10] Fukuyama, F. (1999). The Great Disruption: Human Nature and the Reconstitution of Social Order. New York: Free Press.

[11] Yerznkyan, B. H., Delibasic, M., Grgurevic, N. (2014). Institutsionalnoe povedenie: teoreticheskie voprosy i prakticheskie proyavlenia [Institutional Behavior: Theoretical Issues and Practical Realization], Ekonomicheskaya nauka sovremennoy Rossii [Economics of Contemporary Russia], 4: 19-30.

[12] Yerznkyan, B. H. (2013a). V prostranstve rynochnykh I nerynochnykh vzaimodeystviy: individualnye, organizatsionnye I natsionalnye otlichiya [In the Space of Market and Non-Market Interactions: Individual, Institutional, and Country-Level Differences], Ekonomicheskaya nauka sovremennoy Rossii [Economics of Contemporary Russia], 3: $37-58$.

[13] Yerznkyan, B. H. (2013b). Institutsionalnye osobennosti rynochnykh I nerynochnykh transaktsiy/interaktsiy [Institutional Features of Market and Non-Market Transactions/Interactions], Zhurnal institutsionalnykh issledovaniy [Journal of Institutional Studies], 5 (4): 58-77.

[14] Keizer, P., Spithoven, A. (2009). Cultural Foundation of Distribution of Income: The Dutch Case. Journal of Economic
Issues, 43 (2): 513-522.

[15] Lijphart, A. (1968). Politics of Accommodation: Pluralism and Democracy in the Netherlands. Berkely and Los Angeles: University of California Press.

[16] Putnam, R., Leonardi, R., Nanetti, R. Y. (1993). Making Democracy Work. Princeton, NJ: Princeton University Press.

[17] Alesina, A., Giuliano, P. (2013). Culture and Institutions. NBER Working Paper No. 19750. Cambridge, MA, 67.

[18] Evstigneeva, L. P., Evstigneev, R. N. (2011). Novye grani mentalnosti: Sinergeticheskiy podkhod [New Sides of Mentality: Synergetic Approach]. Moscow: LENAND.

[19] Elazar, D. J. (1966). American Federalism: A View from the States. New York: Harper \& Row.

[20] Wirt, F. M. (1991). "Soft" Concepts and "Hard" Data: A Research Review of Elazar's Political Culture. PUBLIUS: The Journal of Federalism, 21 (2): 1-13.

[21] Boeckelman, K. (1991). Political Culture and State Development Policy. PUBLIUS: The Journal of Federalism, 21 (2): 49-81.

[22] Stiglitz, J. E. (2003). The Roaring Nineties. Seeds of Destruction. London: Penguin.

[23] Lvov, D. S. (2005). O reformatsionnom potentsiale ekonomicheskoy nauki [On Reformation Potential of Economic Science] / Preprint WP/2005/185. Moscow: CEMI RAS.

[24] Kolodko, G. V. (2000). Ot shoka k terapii (politicheskaya ekonomiya postsotsialisticheskikh preobrazovaniy) [From Shock to Therapy (Political Economy of Post-Socialistic Reforms)]. Moscow: Expert.

[25] Martishin, E. M. (2015). Evolutsionno-institutsionalnye osnovy sovremennogo reformirovania [EvolutionaryInstitutional Grounds of the Modern Reformation]. Theory and Practice of Institutional Reforms in Russia / Collection of scientific works ed. by B. H. Yerznkyan. Issue 34. Moscow, CEMI RAS: 20-27.

[26] Arkhipov, A. Y., Yerznkyan, B. H., Martishin, E. M. (2015). Anatomy of the "Economic Miracle". European Research Studies, 18 (3): 7-20.

[27] Stiglitz, J. E. (2002) Globalization and Its Discontents. London: Allen Lane. The Penguin Press.

[28] Vardanyan, A. (2011). China and India: Major Differences of Doing Business. Theory and Practice of Institutional Reforms in Russia / Collection of scientific works ed. by B. $H$. Yerznkyan. Issue 20. Moscow: CEMI RAS, 105-109.

[29] Yerznkyan, B. H. (2014). Kognitivnye aspekty institutsionalnogo razvitiya sotsialnykh system [Cognitive Aspects of Institutional Development of Social Systems]. Terra Economicus, 12 (1), 53-72.

[30] Rutland, P. (2009). Post-Socialist States and the Evolution of a New Development Model: Russia and China Compared. PostCommunist transformations: the countries of Central and Eastern Europe and Russia in comparative perspective / ed. by Hayashi Tadayaki and Ogushi Atsushi. Sapporo: Slavic Research Center, Hokkaido University (Slavic Eurasian Studies; No. 21), 49-71. 